DOI: 10.20472/IAC.2017.33.001

\author{
NABA KUMAR ADAK \\ SABANG SAJANIKANTA MAHAVIDYALAYA, India
}

\title{
BANKS CANNOT EITHER MULTIPLY OR INCREASE THE AMOUNT OF MONEY OR CREATE DEPOSITS WITHOUT BACKING OF MATCHING RESERVE; ONLY CENTRAL BANK CREATES MONEY
}

\begin{abstract}
:
This paper presents a critical analysis of whether banks can multiply their available existing deposits of money, that is their liability, and or whether banks can create new money and thereby increase money supply. Economists held different views. Some argue that individual bank cannot multiply credit. Some view individual bank can multiply credit if the borrowers purchase with the borrowed money and, then, the sellers deposit successively the same money in the same bank, the money can be multiplied to the extent of credit divided by reserve ratio times. Some others argue that banks don't need deposit at all; it can create money when it gives loan and deposit it in the borrower's account. They are of the view that "The money supply is created as 'fairy dust' produced by the banks individually, "out of thin air". (Werner 2014, P1). From the critical review of these theories, some important issues come to the surface. First, Money cannot be multiplied, second, money cannot be created out of thin air, third, what is increased is only the IOUs from the banks to their customers and from the customers to their banks, fourth, as banks are bound to keep certain percent of their reserve (deposit) in the custody of the central bank, in every successive deposit the quantity of money reduces and after the final deposit and lending all money will be placed at the custody of the central bank. No money will be there in the economy to repay the loan and its interest. Repeated depositing and lending of same money, thus, reduces the money available for economic activities.
\end{abstract}

\section{Keywords:}

Credit creation, money multiplier, financial intermediary, reserve ratio, central bank reserve, deposit, IOU, creation and destruction of money 


\section{Introduction}

Economists are of the opinion that severe credit crunch in the banking sector has caused the recent great recession of 2008. They hold banks responsible for causing the credit crunch. They argue that banks multiply and or create money through the process of money lending. Thus, banks increase money supply that ultimately leads to credit crunch. However, they are divided in two groups. Some economists, mostly the traditional economists and Chicago School of economics view that banks multiply money when they create deposit the lent money in the borrowers' account. The heterodox economists; mostly Modern Monetary Theorists, Austrian School of economics, Bank of England, and PositiveMoney view that banks do not lend money out of their reserve balances; they create New Money when they create deposit in the borrowers' account. They even argue that money is created when borrower takes loan and money is destroyed when the borrower repays the loan. On the basis of their understanding that banks increase money supply either through multiplying the existing money or through creating New Money by creating deposit in the borrowers' accounts; both group of economists argue that Banks should be ripped of the power of such credit (money) creation.

The purpose of this paper is to establish that Banks cannot either multiply or increase the amount of existing Money or create New Money through the process of credit creation in the borrowers' account. The money that is supposed to be increased either through multiplication or through creation of New Money is not the currency that the Central Bank issues. The economists consider these deposits as money and count them in different headings like Money 1(M1), Money 2 (M2), Money 3 (M3), Money 4 (M4), etc. The purpose of this paper is also to establish that these M1, M2, M3, and M4 cannot be treated as money at all. Some of them are just records, in the ledger-book of the banks, of how much money is deposited and how much money is lent or invested. Some of them, travelers' cheques, certificates of bonds, term deposits etc are nothing but IOUs from the banks to their holders. Some of the assets like promissory note from the borrowers are IOUs from the borrowers to the banks. The other purpose of this paper is to show that IOUs are not money. The cheque issued by the depositor is not money; it is a promissory note or IOU. Therefore, increase of them cannot be considered as increase in money supply. It is also the purpose of this paper is to establish that banks cannot and do not increase money supply through extending loans; on the contrary, in every successive deposit and lending, some money is withdrawn from the circulation causing liquidity crunch in the economy. Besides, money cannot be created through lending and cannot be destroyed through repayment of the loan. The another purpose of this paper is to establish that banks cannot and do not influence money supply, because they cannot and do not multiply money or create New Money. Only the Central Bank has the sole authority to issue money and it controls the money supply through using some monetary tools. It seems that, as there is no rational and universally accepted definition of money, the economists are confused what is to be treated as money and what is not money. They are even ready to consider everything, like 
traveler's cheques, cheques issued by the depositors, which can be used only after converted into money, as money. Therefore, the related purpose of this paper is to show that due to the absence of a clear cut and universally accepted definition of money, economists are misled; they cannot identify what are the systemic defects in the monetary system and practices, and fall prey to such imaginary thinking that banks increase supply of money either through multiplying the existing money or through creating New Money when they create deposit in the borrowers' accounts. Therefore, the purpose of this paper is to suggest that economists should first find a suitable and practical definition of money before they venture to solve the economic maladies.

The above findings are unique in the study of economics as I have not found any mention of these findings in writings of any economists. Therefore, these findings are new additions to economics literature and to the knowledge of economics theories and practices.

At first, in the 2nd section, I will make literature review, where I will explain these two theories in detail: Theory of money (credit) multiplication through fractional reserve banking and the credit creation theory of banking. Then in the 3rd section, I will critically examine the validity of each of these two theories separately: Assessment of the theory of money multiplication through fractional reserve banking and Assessment of the Credit creation theory of banking. Thereafter in 4th section, I will elaborate my findings. The findings are: 4.1. Most of the economists claim that commercial banks themselves create deposits or money; however, no deposit or money is really created. 4.2. Currency (M0) issued by the Central Banks is not IOU; the so-called "money" (M1, M2, M3 and M4) are IOUs and not money; and difference between the IOU and Money. 4.3. Banks are essentially financial intermediaries; they cannot create money. 4.4. What is created and destroyed by the banks are not money; they are IOUs or promissory notes either of the bank to its depositors or of the depositors to the bank. 4.5. Banks cannot and do not control the money supply; only the Central Bank creates money and controls the money supply by using its monetary tools like setting target of interest rate or lending money to the banks through its discount window. 4.6. Fractional Reserve Banking does not multiply or increase money supply; on the contrary money is withdrawn from the circulation every time money is deposited in the bank as bank is bound to keep aside a percentage of the deposit in the custody of the Central Bank; this causes liquidity crunch and recession. 4.7. Absence of any rational and universal definition of money is the sole cause of misunderstanding of how economics works. 4.8. The immediate concern of the economists should be to make money debt-free that is the primary cause of many economic maladies throughout the globe. In section 5, what is new in this paper, I will sum up how my findings enrich the knowledge of the economics theories and practices. Thereafter, in the conclusion and recommendation, section 6 , I will explain the implication of my findings on the economic theory and my recommendations for further research.

\section{Literature review}

Two distinct and mutually exclusive theories regarding creation and supply of money by the banks are now prevalent. Which of these two theories, regarding how credit money and 
banking work and how they influence monetary and financial policies, is correct has not yet been ascertained. The two theories are:

\subsection{Theory of money (credit) multiplication through fractional reserve banking}

According to this view, banks as intermediaries accept loan from the public as deposits (liability of the bank) and lend those deposits to the borrowers and simultaneously deposit the same lent money in the borrowers account in the same bank. "Banks use depositors' funds to make loans and to purchase others assets". (Krugman and Obstfeld, 2000, P.659). According to Keynes, "he [the banker] is also acting as a middleman in respect of a particular type of lending, receiving deposits from the public which he employs in purchasing securities, or in making loans to industry and trade mainly to meet demands for working capital."' (Keynes 1930, P 213). Stein opines that "Overall, our synthesis of these stylized facts is that banks are in the business of taking deposits and investing these deposits in fixed income assets that have certain well-defined risk and liquidity attributes but which can be either loans or securities." (Stein 2014, P 7). Thus, some economists view that banks act as purely financial intermediaries. "But those financial institutions that are counterparties of the Bank of Japan obtain their funding primarily from the money that depositors have deposited with them. This money they cannot pass on for consumption and capital investment, because they have to lend it at interest to earn money. In other words, for this money to support the economy, these financial institutions must lend it to firms and individuals. Those borrowers must then use it to buy assets such as machinery or housing or services". (Koo and Fujita 1997, P 31). In this theory, banks like other nonbanking financial intermediaries should at first collect saving deposits to be able to lend.

Some economists consider that an individual bank can multiply money or credit if the same money is deposited by different customers at different times repeatedly in the same bank. Huitson presented this view in the following description. "Mr. Smith deposits $£ 1,000$ into his Barclays account. Knowing the usual tendencies of their customers, the bank holds back only a fraction of this deposit as 'reserves' (the reserve ratio functions as a brake on the scale of money creation - the higher the reserve level the less new money can be created from a given deposit). With a reserve ratio of $10 \%, £ 100$ of Mr. Smith's deposit is retained and the other $£ 900$ is "lent out". Or rather, since it still appears under Mr. Smith's assets as a full $£ 1,000$, the $£ 900$ is created and lent to Mr. Jones who now has $£ 900$ in his account. $£ 1,000$ just became $£ 1,900$. Upon purchasing a new television, Mr. Jones' $£ 900$ loan is now deposited into the sellers HSBC account. HSBC in turn will hold back only a fraction of the $£ 900$ deposited, $10 \%$, and loan out the remaining $£ 810$. The initial $£ 1,000$ deposit is now $£ 2,710$. And so on. After 204 cycles, $£ 1,000$ becomes $£ 10,000$ of bank deposits money." (Huitson Feb. 2012, P 4).

Some economists consider that banks act as financial intermediaries between the savers and the borrowers. "banks also serve as intermediaries between savers and investors-as loan banks. In this function they first offer and enter into time-contracts with savers. Savers 
loan money to the bank for a specified-shorter or longer-period of time in exchange for the banks' contractual obligation of future repayment plus some additional interest return. From the point of view of savers, they exchange present money for a promise of future money: the interest return constituting their reward for performing the function of waiting.

Having thus acquired temporary ownership of savings from savers, the bank then re-loans the same money to investors (including itself) in exchange for the latter's obligation of future repayment and interest. The interest differential-the difference between the interest paid to savers and that charged to borrowers- represents the price for intermediating between savers and investors and constitutes the loan bank's income." (Hans-Hermann Hoppe 1994, P 66)

However, banks are required to keep certain portion of the deposit they receive for servicing customer payments. "The required reserves are expressed as a fraction of the bank's customer deposits; the required fraction is called the reserve ratio. The reserve ratio varies significantly from country to country and from time to time. Some major countries have reserve ratios of zero, in Spain and Switzerland it is now about 2\%; in the US it is about 10\%; in some countries (e.g. Turkey) it has been at times higher than $60 \%$. These numbers are approximate (even when precise), because not all deposits contribute equally to basis to which the reserve ratio is applied. For example, in the US term deposits do not count toward reserve requirements, and some deposits are counted at $5 \%$ instead of $10 \%$." (Blanc, Mariano \& David W. Peterson, Undated, P 1).

Some economists think that Banks can multiply money or credit through multiple deposits and lending of the same money. However, banks cannot take deposit and lend the same money for unlimited times; because they must keep some portion of the money as reserve every time they accept the money as deposit. This is called fractional deposit keeping. Thus, every time it accepts the same money as deposit, the loanable fund reduces to the extent of the fraction of money that is kept as reserve. Therefore, banks can no more lend when the amount of money is reduced to almost nil due to successive fractional reservekeeping. Therefore, Banks' power of multiplying the same money is limited by the percentage of reserve that the banks must keep each time they accept deposit. "The most simple money multiplier described in textbooks links reservable deposits to bank reserves according to equation (1): $\Delta D=(1 / \mathrm{r}) \Delta \mathrm{R}$, where $\Delta R$ refers to changes in total reserves, $\Delta D$ refers to changes in reservable deposits, $r$ is the required reserves ratio, and $1 / r$ is the simple multiplier. Open market purchases increase the quantity of reserves, because of fractional reserve accounting, banks can lend out extra funds, and the extra lending increases both lending and the money supply because loans are created as demand deposits. Money increases by $1 / r$ and lending increases by $(1-r) / r$." (Seth B. Carpenter and Selva Demiralp 2010, P 3)

"Banks can build up deposits by increasing loans and investments so long as they keep enough currency on hand to redeem whatever amounts the holders of deposits want to convert into currency. This unique attribute of the banking business was discovered many 
centuries ago. ... Such expansion cannot continue beyond the point where the amount of reserves that all banks have is just sufficient to satisfy legal requirements under our "fractional reserve" system." (Federal Reserve Bank of Chicago- Undated).

For Example, if required requirement is $10 \%$, then the maximum deposit creation by the bank(s) may be expanded up to ten times of the initial deposit. How much the initial deposit may grow is computed by a theory of Initial Deposit (ID)/ Reserve Requirement (RR). "For example, if reserves of 20 percent were required, deposits could expand only until they were five times as large as reserves. Reserves of $\$ 10$ million could support deposits of $\$ 50$ million. The lower the percentage requirement, the greater is the deposit expansion that can be supported by each additional reserve dollar. Thus, the legal reserve ratios together with the dollar amount of bank reserves are the factors that set the upper limit to money creation." (Federal Reserve Bank of Chicago- Undated). "The money multiplier view of credit determination is still pervasive in standard macroeconomic textbooks including, for example, Abel and Bernanke (2005), Mishkin (2004), and Walsh (2003)." (Disyatat, Piti2010, P 5)

The following Table No.1 is the typical example of how credit-creation and money-supply are increased.

\section{Assets}

Liabilities

\begin{tabular}{|c|c|c|c|c|c|}
\hline & $\begin{array}{l}\text { Total } \\
\text { reserve }\end{array}$ & $\begin{array}{l}\mathrm{RR} \\
10 \%\end{array}$ & Excess reserve & $\begin{array}{l}\text { Loans and } \\
\text { Investments }\end{array}$ & Deposits \\
\hline $\begin{array}{l}\text { Reserve } \\
\text { provided }\end{array}$ & 10,000 & 1,000 & 9,000 & --- & 10,000 \\
\hline Stage 1 & 10,000 & 1,900 & 8,100 & 9,000 & 19,000 \\
\hline Stage 2 & 10,000 & 2,710 & 7,290 & 17,100 & 27,100 \\
\hline Stage 3 & 10,000 & 3,439 & 6,561 & 24,390 & 34,390 \\
\hline Stage 4 & 10,000 & 4,095 & 5,905 & 30,951 & 40,951 \\
\hline Stage 5 & 10,000 & 4,686 & 5,314 & 36,856 & 48,856 \\
\hline Stage 6 & 10,000 & 5,217 & 4,783 & 42,170 & 52,170 \\
\hline Stage 7 & 10,000 & 5,695 & 4,305 & 46,953 & 56,953 \\
\hline Stage 8 & 10,000 & 6,126 & 3,874 & 51,258 & 61,258 \\
\hline Stage 9 & 10,000 & 6,513 & 3,487 & 55,132 & 65,132 \\
\hline Stage 10 & 10,000 & 6,862 & 3,138 & 58,619 & 68,619 \\
\hline Stage 20 & 10,000 & 8,906 & 1,094 & 79.058 & 89.058 \\
\hline $\begin{array}{l}\text { Final } \\
\text { Stage }\end{array}$ & 10,000 & 10,000 & 00000 & 90,000 & $1,00,000$ \\
\hline
\end{tabular}

Adapted from "Modern Money Mechanics- A Workbook on Bank Reserves and Deposit Expansion" - Federal Reserve Bank of Chicago- Undated, P 11. 
"Thus through stage after stage of expansion, "money" can grow to a total of 10 times the new reserves supplied to the banking system as the new deposits created by loans at each stage are added to those created at all earlier stages and those supplied by the initial reserve-creating action." (Federal Reserve Bank of Chicago- Undated)

\subsection{The Credit Creation Theory of Banking}

Richard A. Werner explains this theory thus: "In the process of making loaned money available in the borrower's bank account, it was found that bank did not transfer the money away from other internal or external accounts, resulting in a rejection of both the fractional reserve theory and the financial intermediation theory. Instead, it was found that the bank newly 'invented' the funds by crediting the borrower's account with a deposit, although no such deposit had taken place. This is in line with the claims of the credit creation theory." (Werner Jan. 2015). "New money is principally created by commercial banks when they extend or create credit, either through making loans, including overdrafts, or buying existing assets. In creating credit, banks simultaneously create brand new deposits in our bank accounts, which, to all intents and purposes, is money." (Josh Ryan-Collins et al, P 6). "Banks do not need to wait for a customer to deposit money before they can make a new loan to someone else. In fact, it is exactly the opposite: the making of a loan creates a new deposit in the borrower's account." (Josh Ryan-Collins et al, 2012, P 7). "Each and every time a bank makes a loan, new bank credit is created - new deposits - brand new money. (Graham Towers, 1939, former Governor of the Central Bank of Canada, ibid, p18)", (Quoted in Huitson Feb. 2012, P 3). "Subject only but crucially to confidence in their soundness, banks extend credit by simply increasing the borrowing customer's current account, which can be paid away to wherever the borrower wants by the bank "writing a cheque on itself". That is, banks extend credit by creating money. (Paul Tucker, Deputy Governor at the Bank of England and member of MPC, 2007, ibid, P.22)", (Quoted in Huitson, $P$ 5). "In other words, money is created as book-entry by purchasing assets or entering credits on the left side of the balance-sheet and corresponding deposits on the right side. In other words, credit is created out of thin air." (Washington, P 1). "Money is created by bank lending. When a bank grants a loan, it books the loan as an asset and the newly created deposit as a liability. Therefore, when banks lend to borrowers, they thereby create deposits (initially held by the borrowers). (Ponomarenko, P 5). "The banks in their lending business are not only not limited by their own capital; they are not, at least not immediately, limited by any capital whatever; by concentrating in their hands almost all payments, they themselves create the money required" (Wicksell 1907, P 214). According to this theory, banks are not financial intermediaries that collect deposits and lend out only those deposits. This theory considers that every single bank creates credit (money) when it gives loan. "A bank is therefore not an office for "borrowing" and "crediting" money, but it is a Manufactory of Credit." [Macleod 1891, II/2, P594). (Quoted in Werner 2014, P 3). "The fundamental idea is that bank lending is never constrained by the deposits that flow into banks—since banks create deposits when they lend." (Fullwiler, Kelton, \& Wray 2012, P- 
2). "Most money in the modern economy is in the form of bank deposits, which are created by commercial banks themselves." (McLeay, Radia \& Thomas 2014, P 4). .

"Money is created by bank lending. When a bank grants a loan, it books the loan as an asset and the newly created deposit as a liability. ... This mechanism, which is present in a number of comprehensive (if somewhat heterogeneous) theoretical economic models (Goodley and Lavoie (2007), Jakab and Kumhof (2015), Brunnermeier and Sannikov (2016), Hanson et al. (2015)) and has found empirical support (Badarudin et al. (2013), Werner (2014)), is widely accepted as state of the art in monetary analysis (ECB (2011), McLeay et al. (2014), Borio and Disyatat (2015))." (Ponomarenko, Alexey 2016, P 5)

The economists who support the Credit Creation Theory completely ignore the fact that savings increase the deposits of the bank. They argue, "Saving does not by itself increase the deposits or 'funds available' for banks to lend" (McLeay 2014, P 2) and "bank deposits are mostly created by commercial banks themselves" (McLeay 2014, P 2) and "Commercial banks create money, in the form of bank deposits, by making new loans" (McLeay 2014, P 3). McLeay et al writes, "For this reason, some economists [James Tobin, 1963] have referred to bank deposits as 'fountain pen money, created at the stroke of bankers' pens when they approve loans" (McLeay 2014, P 3). McLeay writes, "Bank deposits are simply a record of how much the bank itself owes its customers. So they are a liability of the bank, not an asset that could be lent out" (McLeay 2014, P 3). "A related misconception is that banks can lend out their reserves. Reserves can only be lent between banks, since consumers do not have access to reserves accounts at the Bank of England." (McLeay 2014, P 3). "When banks make additional loans they are matched by extra deposits - the amount of reserves does not change" (McLeay 2014, P 12)

\section{Assessment of the two theories regarding money creation and increase by banks}

\subsection{Assessment of the Money multiplier theory}

\section{Banks cannot multiply money through fractional reserve banking}

The in-depth scrutiny of the money multiplier theory reveals that this theory is impracticable and has serious limitations. It may also happen like the following. A buys something from $B$ and gives $\$ 100$, B lends the money to $C$. C buys something from $D$ with that money, $D$ lends the money to E, E keeps the money with him. None of them is a bank. Almost the same process is repeated as has been narrated in previous pages relating to the so called money multiplier process by a bank. Economists do not call this process as money creation because these are not recorded in the bank's ledger book. "Were any additional dollars created here? No, the bank recorded a $\$ 100$ liability on its balance sheet when it accepted your deposit and recorded a $\$ 100$ asset when it made the $\$ 95$ loan an added $\$ 5$ to its reserve account. I don't see any magic or multiplication going on here." (Cribbin, David 2016) 
Besides, what is said to be multiplication of money is not really a multiplication. Total amount of money that is in the economy is not increased at all by the so-called multiplication. It is not a multiplication at all. It is the velocity of money or how many times the money has been transferred from one hand to another hand. Velocity or circulation of money can be done in various ways, through buying and selling, and through lending and borrowing, through paying tax, dividend and interest; through investment and so on.

However, neither the bank nor the depositor is creating money. Bank is acting as an intermediary between the saver/ depositor and the borrower. It is one of the way through which we can transfer/ circulate money from one hand to another hand. Banks act merely as intermediaries between the lenders and the borrowers. The deposits that are created and recorded as deposits in the banks' ledger books successively in the accounts of different borrowers are merely records of transfer of money from one hand to another hand; money is not created and or increased. Take an example, some money is transferred from one hand to other hands successively for ten times in a day through purchases in the market. The total value of the volume of commodities that are sold/ bought is ten times the value of the money that is transferred in all these ten transactions. Economists do not say that money is created ten times; they term it as velocity of circulation of money. When a bank creates credit and debit for ten times (if the RR is 10\%), economists treat this process as creation of money for ten times; they do not treat it as another form of use/ circulation/ velocity of money. In the above case, the money has been transferred between the bank and its customers (A, B, C, D, and E) consecutively. Money is not really created by the bank when it deposits in the borrower's account the money it has already lent, as money is also not created when it is transferred from one hand to another hand through purchases. The deposit, that the bank creates when it lends, is debited from the bank's credit; credit becomes equal to debit and they neutralize one another; no money is created; only the money is transferred. Therefore, Roche is wrong when he states, "over $90 \%$ of the money supply is created by private banks" (Roche 2011, P 9), or "You could also think of the borrower as creating the loan" (Roche 2011, P 28).

"Credit is a very powerful, indeed the most powerful, means of quickening the circulation of money." (Wicksell 1946, P 65). The "influence of credit on the currency may, under all circumstances, be regarded as accelerating the circulation of money." (Wicksell 1946, P 67). "The occasions on which credit actually replaces money [commodity money] and thereby renders it superfluous may, quite simply be regarded as special cases of the general acceleration of circulation; for instead of purely physical transfer we have a virtual i.e. a merely imaginary or possible transfer, but of the same effectiveness" (Wicksell 1946, $P$ 67). And "If ... more of the medium of exchange were required, this would be obtained quite simply by the [single] bank increasing its discounting of bills or its lending in general, by which a corresponding flow of deposits would automatically flow in. The virtual velocity of circulation would thus tend to increase to infinity. A very small quantity of money would suffice for a very large turnover". (Wicksell 1946, P 85). 


\subsection{A. In a Table, I have shown how, in reality, this process of money multiplication does not work. It is Table $\mathbf{- 2}$.}

In this case of money multiplication by the banks, depositing-lending-re-depositing-relending, are not done simultaneously but successively. Deposits are not piled up but transferred from one hand to another; extinguishing of the first deposit conditions the possibility for the second deposit of the same money.

Table- 2.The picture of Money multiplication by a bank under the Fractional Reserve System of $10 \%$ reserve ratio will be such:

\begin{tabular}{|c|c|c|c|c|}
\hline & \multicolumn{3}{|l|}{ Asset } & \multirow{2}{*}{\begin{tabular}{|l} 
Liability \\
IOUs of the Bank to the \\
Depositors
\end{tabular}} \\
\hline & $\begin{array}{l}\text { Bank's } \\
\text { Deposit/ } \\
\text { Liability to } \\
\text { depositors }\end{array}$ & $\begin{array}{l}\text { Reserve at } \\
\text { the Central } \\
\text { Bank/ IOU } \\
\text { of the CB }\end{array}$ & $\begin{array}{l}\text { IOUs from the } \\
\text { borrowers to the } \\
\text { Bank }\end{array}$ & \\
\hline $\begin{array}{l}\text { After Deposit of } \\
\$ 10,000 \text { by } \\
1^{\text {st }} \text { customer }\end{array}$ & $\$ 9,000$ & $\$ 1,000$ & & $\begin{array}{l}\text { A Pass Book of } \$ 10,000 \\
\text { to } 1^{\text {st }} \text { depositor }\end{array}$ \\
\hline $\begin{array}{l}\text { After lending } \\
\text { Excess reserve } \\
\text { of } \$ 9,000 \text { to } \\
1 \text { st borrower }\end{array}$ & $\$ 00000$ & $\$ 1000$ & $\begin{array}{l}\text { IOU of } \$ 9.000 \\
\text { From } 1^{\text {st }} \text { borrower } \\
\text { to the Bank }\end{array}$ & $\begin{array}{l}\text { A Pass Book of } \$ 10,000 \\
\text { to } 1^{\text {stdepositor }}\end{array}$ \\
\hline $\begin{array}{l}\text { After } \\
\text { Simultaneous } \\
\text { creation of credit } \\
\text { of } \$ 9,000 \text { in } \\
1^{\text {stborrower's }} \\
\text { account }\end{array}$ & $\$ 8,100$ & $\begin{array}{c}\$ 1,000+ \\
\$ 900\end{array}$ & $\begin{array}{l}\text { IOU of } \$ 9.000 \\
\text { From } 1^{\text {st }} \text { borrower } \\
\text { to the Bank }\end{array}$ & $\begin{array}{l}\text { Two Pass Books: } \\
\$ 10,000 \text { to } 1^{\text {st }} \text { depositor }+ \\
\$ 9,000 \text { to } 1^{\text {stborrower }} \\
\text { cum depositor }\end{array}$ \\
\hline $\begin{array}{l}\text { After withdrawal } \\
\text { of } \$ 9,000 \text { by } \\
1^{\text {st }} \text { borrower }\end{array}$ & $\$ 00000$ & $\begin{array}{l}\$ 1,000 ; \\
\text { IOU of } \$ 900 \\
\text { of the CB } \\
\text { extinguishes }\end{array}$ & $\begin{array}{l}\text { IOU of } \$ 9.000 \\
\text { of the } \\
1^{\text {ST }} \text { borrower }\end{array}$ & $\begin{array}{l}\text { Two Pass Books: } \$ 10,000 \\
\text { to } 1^{\text {st }} \text { depositor. } \\
\text { Pass Book of the } 2^{\text {nd }} \\
\text { depositor extinguishes }\end{array}$ \\
\hline $\begin{array}{l}\text { After deposit } \\
\text { of } \$ 9,000 \text { by } \\
2^{\text {nd }} \text { depositor }\end{array}$ & $\$ 8,100$ & $\begin{array}{l}\$ 1,000+ \\
\$ 900\end{array}$ & $\begin{array}{l}\text { IOU of } \$ 9.000 \\
\text { of the } \\
1 \text { st borrower } \\
\end{array}$ & $\begin{array}{l}\text { Two Pass Books: } \\
\$ 10,000 \text { to } 1^{\text {st }} \text { depositor + } \\
\$ 9,000 \text { to } 2^{\text {nd }} \text { depositor }\end{array}$ \\
\hline $\begin{array}{l}\text { After lending } \\
\text { excess reserve } \\
\text { of } \$ 8,100 \text { to the } \\
2 \text { nd borrower }\end{array}$ & $\$ 00000$ & $\begin{array}{c}\$ 1,000+ \\
\$ 900\end{array}$ & $\begin{array}{l}\text { IOU of } \$ 9.000 \text { of } \\
1^{\text {st }} \text { borrower }+ \\
\text { IOU of } \$ 8,100 \text { of } \\
2^{\text {nd borrower }}\end{array}$ & $\begin{array}{l}\text { Two Pass Books: } \\
\$ 10,000 \text { to } 1^{\text {st }} \text { depositor + } \\
\$ 9.000 \text { to } 2^{\text {nd }} \text { depositor }\end{array}$ \\
\hline $\begin{array}{l}\text { After } \\
\text { Simultaneous } \\
\text { creation of credit } \\
\text { of } \$ 8,100 \text { in } \\
2^{\text {nd }} \text { borrower's } \\
\text { account }\end{array}$ & $\$ 7,290$ & $\begin{array}{r}\$ 1,000 \\
+\$ 900 \\
+\$ 810\end{array}$ & $\begin{array}{l}\text { IOUs: } \$ 9.000 \text { of } \\
1^{\text {st }} \text { borrower }+ \\
\$ 8,100 \text { of } \\
2^{\text {nd borrower }}\end{array}$ & $\begin{array}{l}\text { Three Pass Books: } \\
\$ 10,000 \text { to } 1^{\text {st }} \text { depositor }+ \\
\$ 9,000 \text { to } 2 \text { nd depositor + } \\
\$ 8,100 \text { to } 2^{\text {nd }} \text { borrower } \\
\text { cum depositor }\end{array}$ \\
\hline
\end{tabular}




\begin{tabular}{|c|c|c|c|c|}
\hline $\begin{array}{l}\text { After withdrawal } \\
\text { of } \$ 8,100 \text { by } \\
2^{\text {nd }} \text { borrower }\end{array}$ & $\$ 00000$ & $\begin{array}{r}\$ 1,000 \\
+\$ 900 ; \\
\text { IOU of } \$ 810 \\
\text { of the } \mathrm{CB} \\
\text { extinguishes }\end{array}$ & $\begin{array}{l}\text { IOUs: } \$ 9.000 \text { of } \\
1^{\text {st }} \text { borrower }+ \\
\$ 8,100 \text { of } \\
2^{\text {nd }} \text { borrower }\end{array}$ & $\begin{array}{l}\text { Two Pass Book: } \$ 10,000 \\
\text { to } 1^{\text {st }} \text { depositor }+\$ 9,000 \text { to } \\
2^{\text {nd }} \text { depositor; and Pass } \\
\text { Book of } \$ 8,100 \text { of } 3^{\text {rd }} \\
\text { depositor extinguishes }\end{array}$ \\
\hline & & & & \\
\hline $\begin{array}{l}\text { After the final } \\
\text { withdrawal of } \\
\text { money by the } \\
\text { Last borrower }\end{array}$ & $\$ 0$ & $\begin{array}{r}\$ 1,000 \\
+\$ 900 \\
+\$ 810 \\
+\$ 729 \\
=\ldots \ldots \ldots \\
\$ 10,000\end{array}$ & $\begin{array}{l}\text { IOUs: } \$ 9.000 \text { of } \\
1^{\text {st }} \text { borrower }+ \\
\$ 8,100 \text { of } 2^{\text {nd }} \\
\text { borrower }+\$ 7,290 \\
\text { of } 3^{\text {rd }} \text { borrower } \ldots \\
\ldots \ldots \quad=\$ 90.000\end{array}$ & $\begin{array}{l}\text { Pass Books: } \\
\$ 10,000 \text { to } 1^{\text {st }} \text { depositor }+ \\
\$ 9,000 \text { to } 2 \text { nd depositor }+ \\
\$ 8100 \text { to } 3^{\text {rd }} \text { depositor } \ldots . \\
\ldots \ldots \ldots \ldots \ldots . \\
\quad=\$ 1,00,000\end{array}$ \\
\hline
\end{tabular}

Source: I have prepared this Table-2, showing the real accounting when banks lend and deposit.

\subsection{B. Some observations can be clearly made from the above table:}

It is clear that if the money multiplier process is continued to its logical end in the process of depositing and lending the same money successively in the bank under the system of fractional reserve banking then there will be no money either in the economy or in the bank. All money will be withdrawn from the economy and the bank and be deposited in the central bank as reserve requirement. In the above table it is seen that the whole amount of $\$$ 10,000 is deposited in the central bank at end of the final lending after which there is no money (deposit or reserve) to be lent out or to be deposited. "In a fractional reserve banking system, drains of currency from banks reduce their reserves, and unless the Federal Reserve provides adequate additional amounts of currency and reserves, a multiple contraction of deposits results, reducing the quantity of money." (Anna J. Schwartz -Money Supply)'

Under the fractional reserve system, the primary condition of money multiplier theory to work is that the same money should be deposited, lent, withdrawn by the borrower, redeposited by another person and re-lent till no money is left to be deposited or to be lent. It is seen in the above table that in each successive depositing and lending process the amount of money is being reduced. At the end of the process there is no money in the deposit or liability side of the bank. In the asset side of the bank there remains the initial amount of $\$ 10,000$; but that is in the custody of the central bank. It is seen that after each successive lending the IOUs from the borrowers are increasing; and in each successive deposit cash in hand is reducing and bank's reserve with the central bank is increasing. Money is transferred from the reserve balances (liquid asset of the bank) to the borrower's account when the bank creates deposit in the borrower's account. Therefore, the deposits in the borrower's account should not be accounted or treated as new money that is wrongly claimed to be created. There remains no money in the deposit balance of the borrowers' account after when the money is withdrawn by the borrower. When the first borrower withdraws money from his deposit and spends and if the recipients deposit the same money in the bank, only then the second deposit is created. Thus extinction of the first borrower's deposit conditions the possibility of a second deposit of the same money. It is erroneous to calculate borrower's deposits that have been extinguished as existing deposits or money. What is increased is not money, money has gone to the central bank, 
only lending is increased nine fold, that is an increase of IOUs from the borrowers; and borrowers have no money as they have spent all the money they borrowed. Deposit also is increased tenfold, the initial money of $\$ 10,000$ went to the Central Bank as required fractional reserve, and nine fold deposits are created as IOUs of the banks to the depositor. However, there is no money in the bank. Therefore, no money is created.

The central banks in many countries do not pay interest on the reserve balances collected as reserve requirement. "The Fed doesn't pay interest on reserves, which was the case until late 2008." (Williams, John C., 2012). The net result is there is no money left either in the bank or in the economy. Neither the borrowers are able to repay their loan, nor can the bank pay interest to its depositors (lenders to the bank). The bank reserves do not earn any interest. Bank owes $\$ 1,00,000$ to its depositors and the borrowers owe $\$ 90,000$ to the bank, $\$ 10,000$ is lying with the central bank. The bank has IOUs amounting to $\$ 90,000$ from the borrowers and the depositors have IOUs amounting to $\$ 1,00,000$ from the bank.

Economists claim that deposits are being created and increased. However the fact is that deposits are created when the bank deposits the lent amount of money in the borrowers' account and extinguished when the borrowers withdraw the money from their deposits. It is the pre-condition that the deposit of the first borrower must be extinguished so that the second deposit by the second depositor can be made. If the money deposited in the first borrower's account is not withdrawn and spent second deposit of the same money cannot be possible. Therefore, it is wrong to add all the successive deposits to show that the same money is being multiplied. Deposits are not multiplied or increased; they are transferred successively from one hand to other hands as depositing and lending is going on alternately. Therefore, the claim of the economist that deposits are multiplied is wrong. As there is no deposit, the claim of the economists that these deposits are used as money also is wrong. What increase are the IOUs from the borrowers and the IOUs from the bank.

After successive crediting and lending, the total credit remains the same; it does not grow. Dan Kervick wrote, "But in most cases the borrower will take the borrowed funds on account. The bank will credit the borrower's account with $\$ 10,000$, which in turn represents a liability of the bank. Again, the bank will book a $\$ 10,000$ loan asset, and so the total balance sheet effect will be zero. In the first case the balance sheet effect was zero because a reduction in cash assets was offset by an increase in loan assets. In this second case the balance sheet effect is zero because the increase in the bank's loan assets is offset by a corresponding increase in the bank's liabilities." (Kervick, Dan -2013).

Money is supposed to be used as medium of exchange that is buying and selling. If all the money goes to the central bank through this process of depositing and lending, then the money cannot be used for any productive purposes. Banks will have assets and liabilities and claim on one another, but there will be no money to honor that claim. Neither the bank will be able to meet the customers demand, nor will the customers be able to repay their loan; and with the progress of time interest will continue to accrue on all the borrowings. The Central Banks usually don't pay interest on the reserve that the Financial Intermediaries hold with it as reserve requirement. Therefore, banks will not get money as repayment and interest from their borrowers as well as from the reserves held by the banks in their reserve accounts held at central bank. The IOUs from the banks to the depositors 
will be tenfold if the reserve ratio is ten percent. No economic activity is done, but the economy is burdened with a loan of nine times and the bank is burdened with ten times of the initial sum that has been initially lent by the central bank.

\subsection{Assessment of the Credit creation theory of banking}

Werner argues that the bank creates money 'out of thin air' when it creates deposits in the borrowers' account. "the financial intermediation and fractional reserve theories are not supported by the evidence: Banks do not gather deposits and then lend these out, as the financial intermediation theory assumes. Nor do they draw down their deposits at the central bank in order to lend, as the fractional reserve theory of banking maintains. The empirical facts are only consistent with the credit creation theory of banking. According to this theory, banks can individually create credit and money out of nothing, and they do this when they extend credit. When a loan is granted by a bank, it purchases the loan contract (legally considered a promissory note issued by the borrower), which is reflected by an increase in its assets by the amount of the loan. The borrower 'receives' the 'money' when the bank credits the borrower's account at the bank with the amount of the loan" (Werner Dec. 2014, P 2).

However, Werner is wrong. Banks cannot create any amount of credit without deducting the same amount from its reserve balances and transferring the same to the credit account of the borrowers. What banks lend is essentially reserve and not created out of thin air. Werner himself explains that what is seemed to be deposit in the account of the borrower in not money. He writes,

"The bank, having 'disbursed' the loan, remains in a position where it still owes the money. In other words, the bank does not actually make any money available to the borrower: No transfer of funds from anywhere to the customer or indeed the customer's account takes place. There is no equal reduction in the balance of another account to defray the borrower. Instead, the bank simply re-classified its liabilities, changing the 'accounts payable' obligation arising from the bank loan contract to another liability category called 'customer deposits'.

While the borrower is given the impression that the bank had transferred money from its capital, reserves or other accounts to the borrower's account (as indeed major theories of banking, the financial intermediation and fractional reserve theories, erroneously claim), in reality this is not the case. Neither the bank nor the customer deposited any money, nor were any funds from anywhere outside the bank utilised to make the deposit in the borrower's account. Indeed, there was no depositing of any funds." (Werner Dec. 2014).

Here, Werner accepts that there is no money in the deposit account of the borrower. However, it is absurd to think that bank can create such deposit in the borrower's account where it does not transfer money from its reserve. The deposit, devoid of any money, created by the bank can also not be accepted as money as Werner claims it to be by simply asserting that "However, bank deposits are defined by central banks as being part of the official money supply (as measured in such official 'money supply' aggregates as M1, M2, M3 or M4). This confirms that banks create money when they grant a loan: they invent a 
fictitious customer deposit, which the central bank and all users of our monetary system, consider to be 'money', indistinguishable from 'real' deposits not newly invented by the banks. Thus banks do not just grant credit, they create credit, and simultaneously they create money." (Werner Dec. 2014). However, according to Werner himself it is "a fictitious customer deposit".

However, contrary to Werner's assertion that banks do not need reserve prior to its lending, the fact is that banks necessarily depend on reserve to be able to lend. If it does not have sufficient fund or reserve to be able to lend, it must collect funds from elsewhere (another bank, another depositor or the Central Bank) to match the amount of money it lent and the amount that customer may demand for payment, before it goes insolvent. Why banks are bound to depend on reserves to be able to lending is explained in the following observations of the economists. "The amount of bank deposits in turn influences how much central bank money banks want to hold in reserve (to meet withdrawals by the public, make payments to other banks, or meet regulatory liquidity requirements), which is then, in normal times, supplied on demand by the Bank of England." (McLeay 2014, P 2). "The supply of both reserves and currency (which together make up base money) is determined by banks' demand for reserves both the settlement of payments and to meet demand for currency from their customers - demand that the central bank typically accommodates". (McLeay 2014, P 8). James Tobin views, "An individual bank is not constrained by any fixed quantum of reserves. It can obtain additional reserves to meet requirements by borrowing from the Federal Reserve, by buying "Federal Funds" from other banks, by selling or "running off" short term securities. In short, reserves are available at the discount window and in the money market, at a price." (Tobin, P 14)

"No, banks are not self-funding, either individually or in the aggregate. The "out of thin air" language, while containing elements of truth, can be extremely misleading ... these bank debts are not just so-called debts or pro forma debts. They are real debts which banks must and do routinely pay off in the course of doing everyday business; and the assets a bank uses to pay these debts come from sources external to the bank. A bank cannot simply manufacture its own payment assets from thin air." (Kervick P 4). "If banks could simply summon their assets into existence out of the aether, then every bank in the country could be as rich as an Arabian Gulf emir". (Kervick P 5). "In the US, registered banks can make use of CHIPS, the Clearing House Interbank Payment System. CHIPS has its own account at the Fed, which participating banks pre-fund at the beginning of every business day by transferring money from their own Fed account to the CHIPS account. Net daily payment balances are calculated as the resultant of all of the payment obligations the participating institutions owe to one another, and payments are made by CHIPS by the end of the day to banks that end up with a net positive closing position. If a bank has a negative closing position - that is, if the amount pre-funded is insufficient to cover that days payments - then the bank pays CHIPS what it owes by making another Fedwire transfer from its Fed account to the CHIPS Fed account." (Kervick P 6). "we argue that rather than the central bank controlling the amount of credit that commercial banks can issue, it is the commercial banks that determine the quantity of central bank reserves that the Bank of England must lend to them to be sure of keeping the system functioning." (Josh RyanCollins et al, P 7). This simply means when commercial banks issue loans, they take loan from the central bank to match their required reserve to meet the amount of loans they 
issue. Klein writes, "The bank has two primary sources of funds; the equity originally invested in the firm .... and borrowed funds secured through the issuance of various types of deposits". [Klein 1971, P 208] (Werner 2014, P 10).

Kerkhoff has described how banks adjust their deficits in reserves in case it lends beyond the limit of its excess reserve. [At first], "Banks extend loans (create deposits) based on their own objectives, risk tolerances, and cost of capital. [Then] Banks seek out reserves (if needed) to back their newly created deposits. Central bank adds reserves to the system (if needed) to appropriately maintain the target federal funds rate." (Kerkhoff Nov. 2014, P 4). "Banks extend credit at a faster rate than loans are being repaid. This increases the deposits for these banks and consequently forces them to have to borrow reserves. They look to other banks but other banks do not have excess reserves, and so are not interested in lending out their required reserves because they would have to adjust loans and deposits accordingly to meet their reserve ratio. There is more demand for reserves than there is supply. Thus the banks compete for these reserves, driving the federal funds rate up. If the central bank wants to maintain its target rate, it MUST add reserves to the system. This balances out supply with demand, and the federal funds rate stays near target." (Kerkhoff Nov. 2014, P 4).

"Each depository institution can create loans (and deposits) only to the extent that it has excess reserves. The thing to remember is that new reserves are not created when checks written on one bank are deposited in another bank. (Miller and VanHoose 1993, p. 331)." (Quoted in Werner 2014, P 8)

"First of all, any individual bank does, in fact, have to lend out the money it receives in deposits. Bank loan officers can't just issue checks out of thin air". (Paul Krugman March 2012).

"Where Do Bank Reserves Come From? ... One of the major responsibilities of the Federal Reserve System is to provide the total amount of reserves consistent with the monetary needs of the economy at reasonably stable prices." (Federal Reserve Bank of ChicagoUndated)

"This process can continue until deposits have risen to the point where all the reserves provided by the initial purchase of government securities by the Federal Reserve System are just sufficient to satisfy reserve requirements against the newly created deposits." (Federal Reserve Bank of Chicago- Undated, P 11)

"Loans add to bank deposits but not to bank reserves. Unless excess reserves can be tapped, banks will not have enough reserves to meet the reserve requirements against the new deposits. Likewise, individual banks may incur deficiencies through unexpected deposit outflows and corresponding losses of reserves through clearings. Other banks receive these deposits and can increase their loans accordingly, but the banks that lost them may not be able to reduce outstanding loans or investments in order to restore their reserves to required levels within the required time period. In either case, a bank may borrow reserves temporarily from its Reserve Bank." (Federal Reserve Bank of ChicagoUndated) 


\begin{abstract}
"A bank may incur a reserve deficiency if it makes loans when it has no excess reserves. ... Borrowing from a Federal Reserve Bank to cover such a deficit is accompanied by a direct credit to the bank's reserve account." (Federal Reserve Bank of Chicago- Undated)
\end{abstract}

"We can thus conclude that it is irrelevant for the multiplier process whether the central bank targets the quantity of money or the interest rate. What matters here that the central bank is always ready to accommodate commercial banks' expansion of credit out of thin air. ... Without the central bank's support the likelihood of a sustained multiplier process taking place is close to nil - hence the notion that the money multiplier is not applicable in a truly free market economy." (Shostak, Frank- 2017)

"If individual banks really could create money by "the stroke of a pen or a computer entry", as Mr. Gould contends, why do they bother paying interest on deposits, why do they borrow funds from parent banks overseas, why do they borrow funds in the international market, why do they need to hold some funds in government securities as a liquidity reserve, why do some banks occasionally run out of money when customers lose confidence in them?" (Brash vs. Gould vs. Brash, 2017). "When the loan of Bank A becomes a check that goes into Bank B, the Federal Reserve debits Bank A's reserve account and credits Bank B's. If Bank A's account goes in the red at the end of the day, the Fed automatically treats this as an overdraft and lends the bank the money. Bank $A$ then must clear the overdraft." (Brown, Ellen -2014).

'Positive Money' asserts that, "almost all money is created by commercial banks as they issue loans" (Ben Dyson \& Graham Hodgson March 2016, P 1). However, the 'Positive Money' in its another paper explains that banks do not create money, what seems to be created by the bank is in reality created by the Central Bank and lent to the bank to meet its customer's demand and to match the deficit reserve balance of the bank. It writes, "In reality it is commercial banks, and not the central bank, that drive the money creation process. ... The central bank creates notes and coins in response to demand for physical cash from banks. ... Central bank will always create as much physical cash as is needed to meet that demand.... The central bank supplies whatever quantity of reserves that the banks demand. ... the demand from banks for central bank reserves arises as a result of the need to settle the net payment flows (of deposits) between banks' customers, and central banks will create and lend reserves in order to meet all the demand from banks.... it is bank lending that drives the creation of money. Central bank money is created to support and facilitate this creation of private money. The banks are the primary actor here, whilst the central bank creates state money reactively in response to the actions of the banks." (Ben Dyson, Graham Hodgson \& Frank van Lerven Dec. 2016, pp 7-9)

\title{
4. Findings
}

\subsection{Most of the economists claim that commercial banks themselves create deposits or money}

"When a bank makes a loan to one of its customers it simply credits the customer's account with a higher deposit balance. At that instant, new money is created." (McLeay 2014, P 11). 
"Money today is a form of debt, but a special kind of debt that is accepted as the medium of exchange in the economy. And most of that money takes the form of bank deposits, which are created by commercial banks themselves." (McLeay, Radia \& Thomas 2014: 12). "the dominant form of money in the modern monetary system is issued almost entirely by the private banking system" in the form of bank deposits." (Roche 2011, P-2). "The depositor checks against his balance in the bank as if it were really there, and the recipient of the check looks on it in the same way. So long as not too many depositors ask for money, the promises of the bank are thus able to perform all the functions of money." (Douglas Paul H et al 1939, P 15). "In creating credit, banks simultaneously creates brand new deposits in our bank accounts, which to all intent and purposes, is money." (Josh RyanCollins et al 2012, P 6). "The great majority of the money supply in national economies is created by profit-making banks writing it into their customers' accounts out of thin air as bank loans in electronic bank-account money-not coins or banknotes. They call it "credit," to disguise the fact that it is actually money." (Robertson, James- 2009) "Bank deposits are like currency in one respect - both serves as media of exchange - they are like currency in every respect." (Robertson, James- 2009, P 11). "Money supply originates in the behavior of the central bank and banks. A common distinction made in this respect is the supply of "outside money" provided by the central bank - consisting of banknotes and banks' reserves with the central bank - and "inside money" created by banks, consisting mainly of deposits." (ECB Monthly bulletin- 2011, P 65) "Modern money consists primarily of two types of monetary instruments. The first is the notes and coins issued by central banks (fiat money). This is most commonly understood by the proverbial man on the Clapham omnibus to be money. The second type is composed of bank liabilities, also referred to as deposits, credit money or bank money. The measurement of money supply in modern economies therefore includes measures of both the amount of cash money and bank money." (Vivian, Robert, 2015). "This theory considers that every single bank creates credit (money) when it gives loan." (Werner Jan. 2015). McLeay et al also argue, "Commercial Bank creates money, in the form of bank deposits, by making new loans" (McLeay 2014, P 3).

\subsection{A. However, no deposit or money is really created}

"This confusion occurred as economists do not know what money really is. "An eminent monetary economist [E. S. Shaw, "Money Supply and Stable Economic Growth", in United States Monetary Policy, American Assembly, New York, 1958, pp-49-71], more candid than many of his colleagues, admits that we don't really know what money is." (Tobin James 1963, P 3). "All of the perplexities, confusion, and distress in America arise, not from the defects of the Constitution or Confederation, not from want of honor or virtue, so much as from downright ignorance of the nature of coin, credit, and circulation." John Adams, Founding Father of the American Constitution. (Quoted in, Grignon, Paul - Money and Politics, P 5).

The deposit or credit, that the economists claim to be created when bank writes an amount in the borrowers account, is different from the deposit that savers lend to the bank in their savings accounts. The depositors deposit Central Bank money in the bank; so, what is deposited is money. The commercial banks pay interest on that deposit to the depositor. When commercial bank receives deposit, it issues the depositor an account book in which 
the amount of deposit is mentioned. This account book is the IOU from the commercial bank to the saver-depositor. When a customer takes a loan, the customer gives the commercial bank an IOU stating in it how and when he will repay the debt. Through credit creation in the borrower's account, New Money is not created; what is created is IOU from the banks to the borrower and money is transferred from the reserve account of the bank to the borrower's saving or current account.

Bank deposits (checkable deposit and other deposits) are measured in M1 and M2 etc. However, the currency is considered as M0 or Base Money (BM) or High-Powered Money $(\mathrm{HM}$ or only $\mathrm{H})$. "Monetary Base = Currency + Reserve" (Piffer, Michele- 2011, P 5). "Currency in circulation and reserve balances together are often referred to as "highpowered money" or the "monetary base." (Federal Reserve Bank of Chicago- Undated). "The monetary base is the sum of U.S. currency in circulation and bank reserves held at the Federal Reserve. ... A standard measure of the money stock is M2, which includes currency, and certain deposit and money market accounts." (Williams, John C., 2012, P2). "Broader concepts of money (M2 and M3) include M1 as well as certain other financial assets (such as savings and time deposits at depository institutions and shares in money market mutual funds)" (Federal Reserve Bank of Chicago- Undated). "Today, in the United States, money used in transactions is mainly of three kinds - currency (paper money and coins in the pockets and purses of the public); demand deposits (non-interest bearing checking accounts in banks); and other checkable deposits, such as negotiable order of withdrawal (NOW) accounts, at all depository institutions, including commercial and savings banks, savings and loan associations, and credit unions. Travelers checks also are included in the definition of transactions money." (Federal Reserve Bank of ChicagoUndated). "A standard measure of the money stock is M2, which includes currency, and certain deposit and money market accounts" (John C. Williams, CEO of the Fed of San Francisco July 2012, P 2). "For better or worse, most economists think of M2 as the measure of money. M2 is defined as the sum of currency, checking deposits, savings deposits, retail money market funds, and small time deposits." (Seth B. Carpenter and Selva Demiralp May 2010, Fed Reserve Board, Washington, P 3).

However, 'demand deposits', 'other checkable deposits', and 'Travelers Check' referred to by the Federal Reserve Bank of Chicago and 'certain deposit and money market accounts' referred to by the Fed of San Francisco, and 'checking deposits, savings deposits, retail money market funds, and small time deposits' referred to by Fed Reserve Board, Washington are not money at all.

From the definitions of M0, M1 and M2, it appears that same money is being accounted twice in the calculations of M1 and M2. The checkable deposits are once counted in M0 as reserve of the bank ( $\mathrm{M} 0=$ currency + bank reserves). Again it is accounted in $\mathrm{M} 1$. If the checkable deposits remain in the bank and the holder of that deposit (saver/ depositor) do not withdraw money then that is counted as reserve, a component of $\mathrm{MO}$; and if the depositor withdraws the money from the deposit, the deposit balance reduces to zero. There will be no money in the reserve and the IOU given to the depositor will be extinguished. Simultaneously, the money will enter into circulation, which is a component of M0. Therefore, the deposited money, whether it is in the bank as reserve or in the economy as money in circulation, is a component of M0. If we calculate this same deposited money for calculation of M1, then the same money is being calculated twice, once in M0 
and again in M1. Therefore, deposited money cannot be counted as M1. What banks create is an IOU against the deposit; the banks give that IOU to the depositor. This IOU is not money; it is recognition of borrowing from the depositor by the bank. Therefore, in the same logic, M2, M3 and M4 are also not money; they are just acknowledgement of debt (Account book/ Pass book of the depositor and or the lender).

Pay orders like checks, travelers check are also not money. They are instructions of the depositor to transfer money from his deposit account to some specified recipients on some specific terms. These instruments cannot be treated as money as they cannot be used to buy any goods or for lending purposes. These instruments should be redeemed in money; and only then the money can be used. Besides, these instruments may be dishonored, if there remains no money in the account of the person who writes these instruments.

Only the currency issued by the Money Issue Department of the Central Bank is money. Currency is called High-Powered Money (HM) and counted as M0. The high-powered monetary base has its name derived from the supposed influence through the multiplier on the money supply. (Cecchetti and Schoenholz, 2014, p. 456) It is the sum of currency in circulation and reserve balances." (JakubKondek, 2016, P 16). "Time was when only currency was regarded as money, and the use of bank deposits was regarded as a way of economizing currency and increases the velocity of money." (Tobin James- 1963, P 3). "Unlike governments, bankers cannot create means of payment to finance their own purchases of goods and services." (Robertson, James- 2009, P 11).

\subsection{Currency (MO) issued by the Central Banks is not IOU; the so-called "money" (M1, M2, M3 and M4) are IOUs and not money}

Economists wrongly consider Currency issued by the Central Bank as IOU of the Central Bank to the Commercial Banks. "currency - mostly IOUs from the central bank". (McLeay 2014, P 2) and "Reserves are an IOU from the central bank to commercial banks" (McLeay 2014, P 12). "Even this borrowed money is merely the Reserve Banks' promise to pay money." (Douglas Paul H et al - 1939, P 15).

However, currency is not broad money; it is base money or M0. Broad money is IOU that is drawn on the reserve of currency. Deposits and Reserves are not IOU; they are currency; IOUs like demand draft, bonds, Certificates of demand deposits, Certificates of time deposits, bills of payment, traveler's cheque, and agreements of loan (from banks to their depositors and from depositors to their banks) are drawn on that reserve/ deposits of currency. These IOUs are considered as M1, M2, M3 and M4 etc.

Currency (both coins and paper notes) issued by the central bank are money and not IOU. When the Banking sector of the Central Bank needs money, it transfers government bonds (that it buys from the open market) from its holding to the Money Issue Department. Money Issue Department issues money against those government bonds and keeps a record in its balance sheet; newly created money in Liability side and the government bonds in the Asset side. Then, the Money Issue Department transfers the money to the Banking Department of the Central Bank. The Banking Department lends the money to their commercial banks. Therefore, Central Bank does not owe to the Commercial Banks. On 
the contrary, Commercial Banks remain indebted to the Central Bank. Therefore, central bank money is not an IOU to the commercial banks. According to law, the Central Bank is bound to pay, on demand, the sum of currency (paper note) to its bearer (commercial banks). However, even if the Central Bank gives anything of intrinsic value in exchange of money to the holder of the money (in this case the commercial banks), the loan of the borrower (commercial banks) to the Central Bank will not be redeemed. The commercial banks borrow central bank money giving the Central Bank a written IOU promising that it will repay the debt at a later date and until it repays the debt in full it will keep on paying interest regularly to the Central Bank. The debt (IOU) of the commercial bank will be extinguished/ destroyed only if the commercial bank pays interest regularly and repays the loan in due time. The issuer of the IOU is thus bound to pay interest until he repays the debt in full with accrued interest on the debt. However, the Central Bank does not pay any interest to the commercial banks against the amount of money (so-called IOUs of the Central Bank) that the commercial banks hold. On the contrary, commercial banks pay interest to the central bank. Therefore, central bank money is not IOU; on the contrary, commercial banks receive central bank money as loan, giving IOU to the central bank. Therefore, Central Bank reserves are not IOUs to the commercial banks; but commercial bank borrows Central bank reserves (money) giving an IOU to the Central Bank.

Therefore, some economists consider that credit is not money. "Money is money and credit is credit. They are not the same thing; they are completely different financial animals." (Cribbin, David -2016). "Banks take money in, in the form of deposits, and lend out that very same money and a portion of its reserves to other banking customers in the form of loans. What has been created in these transactions is credit, which is not the same as creating money. No paper, coin or reserve money that didn't already exist is created when a bank makes a loan to a customer. Money that the bank has taken in on deposit and the bank's own reserves are used to make the loan." (Cribbin, David, 2016). "Demand deposits subject to check, though functioning like money in many respects, are not composed of physical money, but are merely promises by the bank to furnish such money on the demands of the respective depositors." (Douglas Paul H et al - 1939, P 14).

If either of these IOUs of the borrowers or of the banks and the IOUs like cheques or payorders is treated as money, then economic activities could be continued and expanded to the extent of the volume of these IOUs, even if there were no currency (issued by the Central Bank) in circulation in the economy. However, no economic activity is possible; in the economy, if there, in the economy, remain only the so-called "money" (M1, M2, M3, and M4 minus currency) created by the banks and no money ( $\mathrm{M} 0$ or High powered money) that is created only by the central bank. Therefore, these IOUs cannot be treated as money as the economists claim them to be. The IOUs are just pay orders with some conditions (like interest, maturity time etc.) or claim that is to be redeemed at any or specified future time. IOUs must be redeemed with M0 or high powered money, which is real money to make any economic activities or transaction possible. Therefore, IOUs are not money in any sense. Nobody can use simultaneously these IOUs and the money against which they are created.

If we accept that bank-lending creates deposits as economists argue, then it should also be accepted that banks do not need deposits from anybody outside. It will also mean that 
banks create its own deposits and need not receive any deposit from whosoever. Then there is no need of banks to compete in the money market for getting deposits or pay interest on the deposit they receive from the saver (depositor). However, it is impossibile for the banks to do without receiving deposits either from individuals, or from other banks or from the Central Bank.

\subsection{A. The differences between money and IOU are:}

1.Money, by nature, is commodity or certificate (token money/ paper money/ electronic money/ plastic money) of right to commodity.

But, IOU is not commodity. It is only a promise to repay the debt of commodity at any future date. Therefore, it is a document/ agreement of loan/ promissory note/ cheque/ bond written on a paper or in electronic form. The promises cannot have physical form. They abstract actions and cannot be commodity.

2. In an exchange when money is paid against a commodity, the exchange is complete. Neither the buyer nor the seller is either a creditor or debtor.

But, the issuer of the IOU remains indebted to the lender of commodity/ commodity money/ certificate of right to some commodity. In an exchange when money is not given and an IOU is issued against the commodity, the exchange is not complete. The exchange will be complete only if the IOU is honored by the issuing authority. If $\mathrm{I}$ issue a cheque on my savings account in the bank and give to someone in exchange of something I buy from him, the exchange will be complete only if my bank give him money (from my account in the bank) in exchange of the cheque. If sufficient balance is not there in my account, the cheque will be dishonored and the exchange will remain incomplete. Therefore, IOU as reliable as money is.

3. In an exchange, when money is given against a purchase, the exchange is complete. The buyer of the commodity is not liable to pay any cost of money (interest) to the seller of commodity.

But, in an exchange, when an IOU is given against a purchase, the exchange is not complete. It is process called lending or borrowing. The buyer (borrower/ debtor) remains liable to pay the cost of money (interest) to the seller (lender/ creditor) of commodity.

4. When money is a commodity; it has the intrinsic (commodity) value. Paper money is created against some reserve of commodity that the issuer of money keeps in his custody and cannot use the reserve for any other purpose. The issuer of money remains liable to redeem the money at a future date when the holder of money presents money for redemption. 
But, IOU is not created against any commodity. The issuer does not keep any commodity as reserve against the IOU. IOU is issued (created) out of nothing. It is expected that the issuer of an IOU will repay the commodity or the value of commodity that he has borrowed at a later date.

5. Commodity money, because of its durability, cannot be extinguished unless it is burned or destroyed. Money does extinguished even if paper money (the representative of the reserve) is torn, burned or destroyed, the commodity against which it is made does not extinguish. After an exchange is completed between commodity and money (commodity money or paper money), money does not extinguished. The receiver (the seller of the commodity who gets the money in exchange of his commodity) of the money can use the money; the value of money remains unchanged.

But, in case of an IOU, when the exchange gets completed (the issuer of the IOU repays the debt associated with the IOU), the IOU becomes extinguished. Neither the receiver nor the issuer of the IOU can use that IOU for any further payments or borrowing or lending.

6. Money is divisible in units. If I pay a shopkeeper a note of $\$ 10$, he may give changes in ten $\$ 1$ s.

But, if I pay the shopkeeper a cheque of $\$ 10$, he will not give me change in unit dollars. First, he will deposit the cheque in his bank account. If the cheque is honored i.e. my bank transfers the amount of $\$ 10$ dollar to the account of the shopkeeper (if there is at least $\$ 10$ in my account), then only the shopkeeper will give me changes. Therefore, IOU is not itself money, it is a pay-order (instruction of payment) of the money against which it is drawn. And if there is less or no money against which the cheque is drawn, then that IOU cannot be used for redemption.

\subsection{B. Therefore, IOU can never be called/ treated as money.}

As IOU is not a commodity and is not created against any reserve of commodity, so IOU cannot be money; because money is either a commodity or a certificate of right to commodity. IOU is just a record of number and of the terms of borrowing or lending of commodity/ commodity money/ certificate of right to commodity. If we keep a record of purchase or sale, that record cannot be money. Similarly, the record of a borrowing (who owes to who and how much and the terms of borrowing and repayment) cannot be treated as money.

\subsection{Banks are essentially financial intermediaries; they cannot create money}

Supporters of credit creation theory argue, "One common misconception is that banks act simply as intermediaries, lending out the deposits that savers place with them. In this view deposits are typically 'created' by the saving decisions of households, and banks then 'lend 
out' those existing deposits to borrowers, for example to companies looking to finance investment or individuals wanting to purchase houses" (McLeay 2014, P 2) and "Bank deposits are simply a record of how much the bank itself owes its customers. So they are a liability of the bank, not an asset that could be lent out" (McLeay 2014, P 3) and that "Saving does not by itself increase the deposits or 'funds available' for banks to lend. Indeed, viewing banks simply as intermediaries ignores the fact that, in reality in the modern economy, commercial banks are the creators of deposit money. This article explains how, rather than banks lending out deposits that are placed with them, the act of lending creates deposits" (McLeay 2014, P 2). "This paper presents the first empirical evidence in the history of banking on the question whether banks can create money out of nothing ... This study establishes for the first time empirically that banks individually create money out of nothing. The money supply is created as 'fairy dust' produced by the banks individually, "out of thin air"." (Werner 2014, Abstract). Thus, according to this theory, banks don't need deposit to be able to lend. "In the ILF [intermediation of loanable funds] model, bank loans represent the intermediation of real savings, or loanable funds, between nonbank savers and non-bank borrowers. But in the real world, the key function of banks is the provision of financing, or the creation of new monetary purchasing power through loans, for a single agent that is both borrower and depositor. The bank therefore creates its own funding, deposits, in the act of lending, in a transaction that involves no intermediation whatsoever." (Jakab, Zoltan\& Michael Kumhof, 2015, P ii).

However, this notion that banks are not dependant on the money created by the Central Bank and can create their own funds is erroneous. "All of which leaves us to wonder: If banks do not lend their depositors' money, why are they always scrambling to get it? Banks advertise to attract depositors, and they pay interest on the funds. What good are our deposits to the bank?" (Brown, Ellen -2014). The banking system has been developed to perform financial service and thereby earn profit. Banks gets deposit from the savers (depositors) at certain percentage of interest. Then the bank lends that money to the borrowers at a higher interest, and thus makes profit from the services it renders to the savers by safe-keeping the money and to the borrowers by meeting fund-requirements. It is wrong to say that banks are not dependant of Central Bank's currency. Money initially enters into the economy from its only source the Central Bank via the commercial banks. Therefore, banks are bound to take loans from the Central banks to cater the demands for loan by the public, the government and the corporate. Only when these loans are spent the money begins to circulate in the economy. Private savers get money from this circulation and saves money in the bank. If the banks do not play the intermediary role of taking loan from the Central Bank and pass the money to the borrowers then economy will get no money, because banks are the link between the Central Bank and the public. "In essence, the central bank creates liquidity that then is lent out by banks, thereby starting the creditdeposit money creation process." (Jan Gottschalk- IMF- 2014). When a bank extends loan without sufficient reserve in its asset side, it takes loan from the Central Bank's discount window. Otherwise, the bank will face insolvency. Besides, it is the function or business of a bank to create profit by borrowing money at a less interest and lending the same money at higher interest. Therefore, banks cannot survive if it does not act as financial intermediaries. 
"Because banks are profit-maximizing firms that earn profits from making loans, they will generally loan out as much of their excess reserves as possible." (Colonel Richard K. et al, 2010). "Banks provide an essential financial function by linking depositors and borrowers. Banks, large and small, serve diverse customers, from individuals to businesses, governments and municipalities. This section reviews the basics of banking, bank innovation, and the role of banks in the economy... In its simplest form, traditional banking involves accepting money from depositors and loaning it to borrowers. Banks serve a variety of customers-individual consumers and businesses of all sizes, as well as federal state and local governments." (American Bankers' Association- 2014). "The phrase "banks create money" forms part of the popular discourse, but it conveys an erroneous representation of the banks' role in the money creation process. The role of banks is primarily that of an intermediary between buyers and sellers in, for example, a transaction involving the purchase of a house." (Vivian, Robert -2015).

\subsection{What is created and destroyed by the banks are not money; they are IOUs or promissory notes either of the bank to the depositors or of the depositors to the bank}

Another serious mistake they made by arguing that the money created through loan deposits are destroyed when the borrower repays the loan. Michael Reiss states, "It [money] gets created when banks make loans and destroyed when loans are repaid." (Michael Reiss Sept. 2013). Positive Money also writes, "Banks create new money in the form of the numbers (bank deposits) that appear in bank accounts, through the accounting process used when they make loans." (Ben Dyson, Graham Hodgson \& Frank van Lerven Dec. 2016, P 3).

McLeay et al explains creation and destruction of money by the commercial banks in the following way: "the household and companies who receive the money created by new lending may take actions that affect the stock of money - they could quickly 'destroy' money by using it to repay their existing debt, for instance" (McLeay 2014, P 1), and "Just as taking out a loan creates new money, the repayment of bank loans destroys money. ... Banks making loans and consumers repaying them are the most significant ways in which bank deposits are created and destroyed in the modern economy." (McLeay et al., 2014, P 3) and "Banks making loans and consumers repaying them are the most significant ways in which bank deposits are created and destroyed in the modern economy ... Deposit creation or destruction will also occur any time the banking sector (including the central bank) buys or sells existing assets from or to consumers, or, more often, from companies or the government" (McLeay 2014, P 4), and "Banks buying and selling government bonds is one particularly important way in which the purchase or sale of existing assets by banks creates and destroys money" (McLeay 2014, P 4) and "Money can also be destroyed through the issuance of long-term debt and equity instruments by banks" (McLeay 2014, P 4) and "Household and companies who receive the newly created money might by undertaking transactions that immediately destroy it, for example by repaying outstanding loans" (McLeay 2014, P 4) and "repaying the bank loans destroys money just as making loans creates it. So, in this case, the balance sheet of consumers in the economy would be returned to the position it was in before the loan was made." (McLeay 2014, P 7). "In a 
fractional reserve system when banks lend out money, that money is created out of thin air by an accounting journal entry, and the money supply goes up by the amount of the loan \& when the loan gets paid off, that money disappears back into thin air and the money supply goes back down which is often also described as "destroying the money". (Macroeconomics beta June 2015). "Most of this account money is created by commercial banks when they extend loans to their customers, loans being, in essence, additions to the money supply, not a mere reshuffling of extant money, as the intermediation model has it. Likewise, repaying bank loans with account Money amounts to extinguishing money, since money spent on loan repayments disappears from the borrower's bank account and thus gets subtracted from the national money supply." (Ravn, lb, 2015, pp 92-93) "How banks destroy money. ... It is also the case that when a loan is repaid to a bank the money used to do so no longer exists." [How money is created and destroyed- 2013, P 9] "For bankcreated money, however, there is an economic mechanism of extinction as well as creation, contraction as well as expansion." (Tobin James-1963, P 12). "At any one time, thousands of people may be creating new money by taking out loans while at the same time thousands may be destroying money by repaying existing loans." (Michael Reiss Sept. 2013).

However, money is not extinguished, only IOUs are extinguished. Money is created against the matching reserve that the Money Issue Department of the Central Bank keeps with it. McLeay et al and Werner mistook IOU (from the bank to the saver or depositor and from the borrower to the bank) as money. When loan is repaid; it is repaid with money. How can these economists argue that money id destroyed when loan is repaid? It clear that loan is repaid with money, only the loan or debt of the borrower (IOU of the borrower) is extinguished or destroyed. Money can only be destroyed only if the matching reserve, against which that money is issued or created, is reduced from the Asset Side of the Balance Sheet of the Money Issue Department of the Central Bank.

McLeay et al and Werner want us to believe/ accept that credit (so-called money) is created out of thin air. Besides, they could not give definite proof in favor of their claim providing the answer from where do the banks make payments to the borrowers if loan is not given out of either the deposit or the bank's reserve held at the central bank or the reserves created through QE.. McLeay writes, "When a bank makes a loan, for example to someone taking out a mortgage to buy a house, it does not typically do so by giving them thousands of pounds worth of banknotes. Instead, it credits their bank account with a bank deposit of the size of the mortgage. At that moment, new money is created. For this reason, some economists have referred to bank deposits as 'fountain pen money', created at the stroke of bankers' pens when they approve loans" (McLeay 2014, P 3). It remains a mystery, if cash (pounds) were not deposited in the borrowers account by the bank, then how money is transferred from the borrowers account to the account of the seller of the house. They also wrote, "Banks buying and selling government bonds is one particular important way in which the purchase or sale of existing assets by banks creates and destroys money" (McLeay 2014, P 4). It is ambiguous to understand that by buying government bonds the bank creates money; whereas, the fact is that when a bank buys government bonds directly from the government, reserve (central bank money) held in the bank's account at the central bank is deducted and is added to the account of the treasury department of the central bank. 


\subsection{Banks cannot and do not control the money supply; only the Central Bank creates money and controls the money supply by using its monetary tools like setting target of interest rate or lending money to the banks through its discount window.}

The credit creation theory claims that banks create loan out of thing air and thus banks are not constrained by the monetary policy of the central bank. "Furthermore, we argue that rather than the central bank controlling the amount of credit that commercial banks can issue, it is the commercial banks that determine the quantity of central bank reserves that the Bank of England must lend to them to be sure of keeping the system functioning." (Goodhart, Charles A.E- 2011, P-7). "Another common misconception is that the Central Bank determines the quantity of loan and deposits in the economy by controlling the quantity of Central Bank money -- the so called 'money multiplier approach" (McLeay 2014, P 2)

McLeay et al are of the opinion that the Central Bank does not determine the quantity of loans and deposits in the economy by controlling the quantity of central bank money. "Rather than controlling the quantity of reserves, central banks today typically implement monetary policy by setting the price of reserves - that is, interest rates" (McLeay 2014, P 2) and "Central banks do not typically choose a quantity of reserves to bring about the desired short-term interest rate. Rather, they focus on prices - setting interest rates." (McLeay 2014, P 8).

McLeay et al and Werner are misled. In a nation's economy, the only source of money is the central bank. Therefore, it is the primary duty/ function of the central bank to lend money whenever genuine borrowers want to borrow. When banks face demand of loans from the households and institutions, the banks arrange loan from its own excess reserve or gets loan from the central bank. It is also the duty of central bank to maintain price-stability by controlling the supply of money in the economy. The tools of the central bank are of mainly two types. One is monetary; it can decease or increase the CRR (Cash Reserve Ratio), SLR (Statutory Liquidity Ratio) to inject more money into the economy or withdraw money from the economy. It also injects and withdraws money through purchasing assets from the banks or selling assets to the banks, if it feels it necessary for maintaining price-stability or money-supply. If all these measure fail to achieve required results, only then the central bank take recourse to using financial tools like decreasing or increasing bank rate and overnight lending rate. By doing so, central bank either gives incentive for more borrowing or dissuades from more borrowing. Therefore, "setting the price of reserve - that is interest rates" becomes necessary only after all other tools fail to achieve desired result and not before other measures are tried.

"Banks don't create money. Only the Federal Reserve can create money. What you and I think of as money, the coins and paper that we carry in our pockets, is only one component of the money supply. Bank reserve on deposits at the Federal Reserve is the other component. Together they make up the Monetary Base and are sometimes referred to as Base Money, or the Money Supply. The Fed and only the FED can expand or contract the monetary base. This is done through open market transactions where the Fed purchases 
or sells interest bearing securities. If the Fed wishes to expand the monetary base it buys securities from the bank and credits the bank's reserve account at the Fed with newly created money in the form of reserves to pay for the transaction. The transaction has the effect of increasing the size of the Fed's balance sheet (it now owns more securities than before the transaction) and increasing the amount of base money (the bank now has more reserves on deposit with the FED) in the system.

If the Fed wants to contract the money supply it performs the opposite type of transaction. It sells securities (reducing the amount of securities the Fed holds on its balance sheet) to the bank from its portfolio, debiting (thus removing money from the bank's reserve account) the bank's reserves at the Fed for the securities sold to that bank. This shrinks the Fed's balance sheet and reduces the amount of base money in the system. By doing so the Fed can add or subtract reserves from the banking system, something that banks cannot do." (Cribbin, David, 2016).

"The Fed conducts expansionary monetary policy by purchasing government securities like Treasury bills (T-bills) through open market operations, lowering the discount rate, lowering the required reserve ratio, or through some combination of the three. Conversely, if the Fed wished to conduct contractionary monetary policy, it would sell T-bills, raise the discount rate, raise the required reserve ratio, or some combination of the three. The ultimate policy objectives of monetary policies are to influence the levels of gross domestic product (GDP), unemployment, and inflation. (Note: in keeping with contemporary economic convention, GDP rather than GNP is used in this note.)" (Appleyard, Melissa M. \& Petra Christmann, 2008, P 1).

Therefore, commercial banks do not control the money supply; on the contrary they follow the rules and guidelines set by the Central Bank occasionally to meet the required moneysupply. The central Bank does not set interest rate target for the fun of it. The Central Bank adjusts or changes the interest rate target to dissuade or encourage borrowing to withdraw or inject money into the economy to keep money supply at its desired level.

\subsection{Fractional reserve banking causes reduction of money supply in the economy; this leads to liquidity crunch and recession}

The economists claim that almost $95 \%$ to $97 \%$ of aggregate money supply in the UK is supplied by the banks through their credit creation. However, these credits or deposits are not real money. Every time money is deposited money is reduced to the extent of the reserve requirement that is to be kept with the Central bank. These reserves held in the Central bank are withdrawn from the circulation in the economy. Over and above, interest payable on the borrowed money also causes regular withdrawal of money from circulation. Thus as credit creation continues, existing aggregate money in circulation is being continuously reduces. To keep the economy functioning, money (to the extent of reduction of money through keeping required reserve in the central bank and through payment of interest to the banks and to the Central Bank) should be injected into the economy.

This is exactly what happened during the recession that started in 2008. "The reason for this is that in a crisis the relationship between the base money and monetary aggregates 
is altered. The money multiplier drops. It is therefore necessary to create more base money so that monetary aggregates remain stable. This is what central banks have done in the current crisis - and rightly so. They have learned the lessons of the Great Depression." (Abrams, Burton A, 2010, P 1). "It indicates that the credit multiplier, too, increased substantially during the financial market boom, but contracted after August 2007. The Lehman Brothers crisis first caused an increase in lending by banks and the multiplier similar to the US. As the crisis progressed, however, the multiplier fell sharply." (Abrams, Burton A, 2010, P 9). "Many loans are not settled with money, but rolled over with fresh credit. Often the final reckoning does not come until an economic crisis hits." (Nolt, James $\mathrm{H}$., 2015). The reason for this collapse is not unlimited lending or credit creation by the bank. The reason is that with the increase of lending, available money in the economy was decreasing correspondingly. IOUs or claims from the depositors to the banks and from banks to the borrowers increased and simultaneously with every increase of claim (IOU); money was being withdrawn from the economy. A time came when there was no money or less money to meet the claims. When this crisis became acute, neither the borrower could repay loan nor could the banks meet the withdrawal demands of their depositors. The recession occurred.

To keep the economy functioning, money has to be injected. The Fed has injected enormous amount of money in the economy. "In 2008-2010 the Fed successfully prevented a money supply collapse by dramatically increasing the monetary base ... So an increase in the monetary base that offsets a decrease in the money multiplier should be sufficient to stabilize any money supply shocks on aggregate expenditures ... holding the money supply constant when an autonomous decrease in the money multiplier occurs is insufficient to prevent a decrease in aggregate demand." (Abrams, Burton A, 2010, P 3).

Therefore, supply of ever increasing amount of money (M0) should be made constantly by the Central Banks keeping pace with the withdrawal of money from the economy through the keeping reserve requirement and paying interest. The so-called money creation (credit creation) by the banks does not help economy to grow if sufficient money is not continuously injected into the economy to offset the withdrawal of money (that is associated with each lending and credit creation) from the economy through keeping reserve and paying interest.

\subsection{Absence of any rational and universally accepted definition of money is the sole cause of misunderstanding how economics works}

There is no clear cut definition of money. "an eminent monetary economist [E. S. Shaw, "Money Supply and Stable Economic Growth", in United States Monetary Policy, American Assembly, New York, 1958, pp. 49-71], more candid than many of his colleagues, admit that we don't really know what money is". (Tobin, P 3). Different economists define money in different way. This is the reason why IOU/ M1 to M4, financial assets are being treated by many economists as money. "Given the near identity of deposits and bank lending, Money and Credit are often used almost inseparably, even interchangeably... (Bank of England, 2008, ibid, p18)" (Quoted in Huitson, P 3). "we have bank deposits created by those commercial banks and included by the Bank of England as part of the money supply (M1 to M4). This final type, commercial bank money, doesn't make up just a fraction of our 
money supply but a full 97.4 percent of it. Credit creation as money creation is even endorsed by central bankers themselves." (Quoted in Huitson, $P$ 3). "Such payment assets have existed in many different forms historically, along with different kinds systems for generating, storing, transferring and regulating these assets. We customarily call these assets "money"." (Dan Kervick, P 1).

The confusion about the nature of money reaches such a pass that economists contradicts even himself in realizing what is money and what is not. Wither writes, "It comes to this that, whenever a bank makes an advance or buys a security, it gives some one the right to draw a cheque upon it, which cheque will be paid in either to it or to some other banks, and so the volume of banking deposits as a whole will be increased and the cash resources of the banks as a whole will be unaltered." (Withers 1918, P 45). Here, Wither clearly expresses that deposits created by the banks are not money and accepts that deposits may increase, but volume of money will remain unchanged. However, this opinion contradicts his statements a few pages earlier and a few pages later in his book. In page 40 he writes, "By this interesting development the manufacture of currency which for centuries has been in the hands of Government, has passed, in regard to a very important part of it, into the hands of companies, working for the convenience of their customers and the profits of their shareholders." (Wither 1918, P 40) Again, in page 72, he writes, "then, it thus appears that credit is the machinery by which a very important part of modern currency is created" (Wither 1918, P 72). He states, "It is an instrument of credit rather than a form of currency, in the sense in which I am using the word" (Wither 1918, P 29). "Nevertheless, it seems to me right to include it since, as a matter of actual practice, the great volume of commercial transactions is day by day settled by means of cheques, and they accordingly fit in with the wider definition of money that has been adopted for the purpose of this book. Such, then, are the forms of money that are now used by economically civilized communities; bank note, government note, cheques and coin. This implies that economists are not sure between the two the currency (central bank note) and the credit (a claim on money written on a paper), which one would be treated as money. (Wither 1918, P 38). Possibly, Withers could not guess that if an "instrument of credit" is treated as "money" then there will be a problem of double counting the same amount of money, once as currency and another time as "money" that is in reality is an "instrument of credit".

The contradictions and misconceptions of McLeay and Withers may be caused by their confusion regarding the definition, character and functions of money and excessive reliance on the notion that IOUs are also money, and absence of their understanding the difference between money and IOU. Therefore, first, we should define money properly, and then we will be able to distinguish between what is money and what is not. This lack of or confusion in understanding money makes the economists to determine how and how much money is supplied to the economy, and what systemic defects in the economics theories and practices should be addressed and cured. 


\subsection{The immediate concern of the economists should be to make money debt-free that is the primary cause of many economic maladies throughout the globe}

It seems to me that the whole problem lies with the misunderstanding of the economists in considering currency as the IOU of the Central Bank to the commercial banks. However, currency is not an IOU. Currency (paper notes or electronic digits) is the certificate of the reserve that the Money Issue Department issues against the reserve it keeps with it. However, the currency enters into the economy as debt when the Central Bank lends it to the commercial banks. Therefore, currency originates as debt-free, but the economy gets it as debt. This confused the economists and they begin to consider currency as debt. As to them currency is debt, so also every IOU is debt. On that assumption they assume that both currency and IOU are money as both are debt.

It seems that it is not the problem whether bank multiply money or create it out of thin air (as we have seen banks cannot either multiply money or create it out of thin air). Banks only expedite the circulation of money by accumulating money from the savers and lending it to the willing borrowers. Therefore, banks are not responsible for the great recessions to occur; what was the real cause was the very process of entry of money into the economy as loan from its birthplace the Central Bank. Money is born free of debt; however, the Central Bank uses it in the form of lending. And, borrowed money should be repaid with accrued interest. However, the amount of money that the Central Bank injects into the economy as loan, it demand more amount of money as repayment. This mismatch between the amount of money borrowed from the Central Bank and the amount of money repayable to the Central Bank causes the liquidity crunch. As the amount of repayment is larger than the borrowed money, borrowers face problem of repaying the loan. Even if all the borrowed money is repaid, yet the borrowers will be defaulter of not paying the interest, because the amount of money that is to be paid as interest has not been injected by the Central Bank. Due to the circulation of money through depositing and lending via the commercial banks the IOUs have been increased and simultaneously money is withdrawn from circulation through payment of interest and reserve requirement. The base of IOUs widened; the amount of money shrank than before. Due to this increasing scarcity of money, borrowers could not repay their loan. As repayment of loans shrank, banks reserve balances could not be replenished and banks, ability to lending also shrank. Exactly this had caused the great recession. Therefore, to get rid of the business cycle or recession, the economists should think how money can enter the economy as debt-free, and not in the way now the Central Bank is practicing to inject money into the economy as loan.

\section{What is New in this Paper?}

Many new concepts have been emerged in this paper. Those concepts have not been put forward by anybody before this paper is written. It has been establish that Banks cannot either multiply or increase the amount of existing Money or create New Money through the process of credit creation in the borrowers' account. The money that is supposed to be increased either through multiplication or through creation of New Money is not the 
currency or money. What are increased are IOUs either from the banks to savers or from the borrowers to the banks. The economists consider these IOUs as money and count them in different headings like Money 1 (M1), Money 2 (M2), Money 3 (M3), Money 4 (M4), etc. It has also been establish that these M1, M2, M3, and M4 cannot be treated as money at all. Some of them are just records, in the ledger-book of the banks, of how much money is deposited and how much money is lent or invested. Some of them, travelers' cheques, certificates of bonds, term deposits etc are nothing but IOUs from the banks to their holders. Some of the assets like promissory note from the borrowers are IOUs from the borrowers to the banks. The cheques issued by the depositors cannot be treated as money. It is established that IOUs are not money. Therefore, increase of them cannot be considered as increase in money supply. We have also seen that banks cannot and do not increase money supply through extending loans; on the contrary, in every successive deposit and lending, some money is withdrawn from the circulation causing liquidity crunch in the economy. Besides, money cannot be created through lending and cannot be destroyed through repayment of the loan. It became clear that banks cannot and do not influence money supply, because they cannot and do not multiply money or create New Money. Only the Central Bank has the sole authority to issue money and it controls the money supply through using some monetary tools. It seems that, as there is no rational and universally accepted definition of money, the economists are confused what is to be treated as money and what is not money. They are even ready to consider everything, like traveler's cheque, checques issued by the depositors, which can be used only after their conversion into money, as money. Due to the absence of a clear cut and universally accepted definition of money, economists are misled; they cannot identify what are the systemic defects in the monetary system and practices, and fall prey to such imaginary thinking that banks increase supply of money either through multiplying the existing money or through creating New Money when they create deposit in the borrowers' accounts. Therefore, the purpose of this paper is to suggest that economists should first find a suitable and practical definition of money before they venture to solve the economic maladies.

\section{Conclusion and recommendation}

From the critical review of the theories regarding money and or credit creation, some important issues come to the surface. First, Money cannot be multiplied, second, money cannot be created out of thin air, third, what is increased is only the IOUs from the banks to their customers and from the customers to their banks, fourth, as banks are bound to keep certain percent of their reserve in the custody of the central bank, in every successive lending and borrowing the quantity of money reduces and after the final lending all money will be placed at the custody of the central bank. No money will be there in the economy to repay the loan and the interest. Repeated depositing and lending of same money, thus, reduces the money available for economic activities. What is seemed to increase in amount of money is in fact the addition of successive borrowing and lending of the same money by the banks and the customers. It is just successive transfers/ circulation of money. It is not increase in money supply; one cannot simultaneously use the money that is seemed to be 
increased. It may be said that during this time period the initial money has used for such and such times creating a total turnover of such and such amount; the same amount of money is transferred again and again. At best, it may be called the velocity of money, not an increase or creation of money. The most important duty of the economists is to define money. Only then it can be ascertained what systemic defect causes the continuous deterioration of the economy. To me it seems that money's entry into the economy from the Central Bank as debt that is to be repaid with interest is the principal cause of most of the economic maladies. Therefore, it is the prime duty of the economists to make money debt-free.

\section{References}

Abrams,Burton A. \& Russell F. Settle (Undated)- Is Money Neutral in the Long Run?- University of Delaware -Working Paper Series- Department of Economics -Alfred Lerner College of Business \& EconomicsUniversity of Delaware- Working Paper No. 2005-04

Abrams, Burton A (2010) -.Money-Multiplier Shocks in a Credit View Model-Working Paper No.. 2010-05-

Appleyard, Melissa M. \& Petra Christmann (2008 - Monetary Policy and the Money Multiplier ResearchGate

American Bankers' Association (2014) - The Business of Banking: What every policy maker needs to know

Anonymous (2013) - How money is created and destroyed: A guide to the euro zone monetary system

Blanc,Mariano\& David W. Peterson (Undated) - Money Multiplier Dynamics and Banking Liquidity Cycles

Brash vs Gould vs Brash (2017) - Money supply- Michael Reddell's blog

Brown, Ellen (2014) Why Do Banks Want Our Deposits: Hint It's Not to Make Loans Web of Debt Blog

Seth B. Carpenter and Selva Demiralp (May 2010) - Money, Reserves, and the Transmission of Monetary Policy: Does the Money Multiplier Exist? - Finance and Economics Discussion Series Divisions of Research \& Statistics and Monetary Affairs, Federal Reserve Board, Washington, D.C.

Check MP142-The Federal Reserve and Monetary Policy - Mary Washington University - cm-macromonetary-policy

Cribbin, David (2016) - Banking and the Laughable 'Money Multiplier' Myth- RealClearMarkets

Disyatat, Piti (2010)- The bank lending channel Revisited - BIS Working Paper -297

Douglas, Paul H., Irving Fisher, Frank D. Graham, Earl J. Hamilton, Willford I. King, \& Charles R. Whittlesey, (1939) - Chicago Univ. et all- A Program for Monetary Reform Monetary Reform

Dyson, Ben \& Graham Hodgson (March 2016) - Accounting for Sovereign Money: Why State-Issued Money is not Debt, Positive Money

Ben Dyson, Graham Hodgson \& Frank van Lerven (Dec. 2016) - Sovereign Money: An Introduction, Positive Money

ECB Monthly bulletin (2011) - The Supply of Money - Bank Behaviour and the Implications for Monetary Analysis- pp63-79 
Federal Reserve Bank of Chicago (Undated) - Modern Money Mechanics- A Workbook on Bank Reserves and Deposit Expansion- Federal Reserve Bank of Chicago

Fullwiler, Scott Stephanie Kelton, L. Randall Wray (Jan. 2012) - Modern Money Theory: A Response to Critics, SSRN Electronic Journal

Grignon, Paul (Undated) - Money and Politics- Incorrect Diagnosis- Wrong cure

Goodhart, Charles A.E. (Forwarded) (2011) -Josh Ryan-Collins, Tony Greenham, Richard Werner, Andrew Jackson -Where does money come from intro- A guide to the UK monetary and banking system- New Economic Foundation

Gottschalk, Jan (2014) - Introduction to Money Creation, IMF

Hagen, Jurgen Von (2009) - The Monetary Mechanics of the Crisis

Hans-Hermann Hoppe (1994) - How is Fiat Money Possible? -or, The Devolution of Money and Credit- - The Review ofAustrian Economics Vo1.7, No. 2: 49-74- ISSN 0889-3047

Huitson, Oliver (Feb. 2012) -- The Uneconomics guide to money creation - Open Democracy

JakubKondek (2016) - Money Multiplier Determinants in Financial Crisis

Jakab, Zoltan\& Michael Kumhof (2015) - Banks are not intermediaries of loanable funds - and why this matters - Bank of England. Working Paper- 529

Josh Ryan-Collins, Toy Greenham, Richard Werner, Andrew Jackson (2012 $2^{\text {nd }}$ edition) -- Where does Money Come From?- A guide to the UK monetary and banking system

Kerkhoff, Mathew (Nov, 2014) -- Are Banks “Reserve Constrained?"- Financial Sense

Kervick, Dan (2013) -Bank Lending and Bank Reserves - New Economic Perspectives

Kervick, Dan (June 2013) -Do Banks Create Money from Thin Air?

Keynes, John Maynard (1930). A Treatise on Money. London: Macmillan.

Klein, Michael A. (1971, May). A theory of the banking firm. Journal of Money, Credit and Banking, 3, 205218.

Koo, Richard, \& Fujita, Shigeru (1997, March 26). Kokaasairyotekikin'yukanwa [Quantitative monetary easing is hardly effective]. KeizaiKyoshitsu, Nikkei, 31.

Krugman, P. R., \& Obstfeld, M. (2000). International economics: Theory and policy, Addison-Wesley world student series. Reading, Mass.: Addison-Wesley.

Paul Krugman (March 2012) - Banking Mysticism, Continued

Lutz, F. A. (1939, May). Velocity analysis and the theory of the creation of deposits. Economica, 6(22), 156169.

Macleod, Henry Dunning (1891). Theory of Credit, Vol. 2., .

Macroeconomics beta (June 2015)- How does the money supply behave when bank loans are repaid? Economics Stack Exchange

McLeay, Michael, Amar Radia and Ryland Thomas (2014) - Money in the modern economy: an introduction, Quarterly Bulletin 2014 Q1, Bank of England, Vol. 54, No. 1 
McLeay, Michael, Amar Radia and Ryland Thomas (2014) - Money creation in the modern economy; Quarterly Bulletin 2014 Q1, Bank of England

Nolt, James H. (2015) - The Myth of the Money Supply, World Policy Journal, World Policy Institute

Otalu, J. A.,Aladesanmi K. A. \&Mary B. Olufayo (July 2014)-- Monetary Policy and Commercial Banks Performance in Nigeria: An Assessment of Credit Creation Role, The International Journal Of Business \& Management (ISSN $2321-8916)$.

Piffer, Michele (2011) - International Monetary Policy- London School of Economics

Ponomarenko, Alexey (May 2016) - A note on money creation in emerging market economics, Bank of Russia, Working Paper-10

Pozsar, Zoltan, Tobias Adrian, Adam Ashcraft \& Hayley Boesky (2012) Shadow Banking- Federal Reserve Bank of New York, Staff Report No. 458

Rankin, Colonel Richard K., Margaret Ray \& Others, 2010- The Federal Reserve and Monetary Policy; Making It Happen

Ravn, Ib (20150 - Explaining money creation by commercial banks: Five analogies for public education - realworld economics review, issue no. 71

Reiss, Michael (Sept 2013) - End Fractional Reserve Banking and Fix the Economy- Positive Money

Robertson, James (2009)- Money from nothing -Yes ! Magazine

Roche, Cullen O. (August, 2011) - Understanding the Modern Monetary System

Samuelson, P. A. (1948)--Economics: An introductory analysis (2. ed.). New York: Mc Grow-Hill

Schwartz, Anna J. (Undated) -Money Supply- Library Economics Liberty- The Concise Encyclopedia of Economics

Shostak Frank (2017) - How Central Banks Enable the Money-Creation Process - Mises Institute

Stein, Jeremy C. (2014, January 3). Banks as patient debt investors. American Economic Association/ American Finance Association Joint Luncheon, Philadelphia, Pennsylvania.

Stiglitz, Joseph (1997). Economics (2nd ed.). New York: W.W. Norton

Tobin, James, (1963) - Commercial Banks as Creators of Money -Cowles Foundation for Research in Economics at Yale University- Discussion Paper No. 159

Vivian, Robert (2015) - Do banks really create money out of thin air? - World Economic Forum

Washington, George (March 2010) - German Central Bank Admits that Credit is Created Out of Thin Air. (A translation from "Money and Monetary Policy" pages 88-93)

Werner, Richard A. (2014) -Can banks individually create money out of nothing?- The Theories and Empirical Evidence -International Review of Financial Analysis, Vol. 36, Dec. 2014, Pages 1-19.

Werner, Richard A. (Dec 2014) - How do banks create money, and why can other firms not do the same? An explanation for the coexistence of lending and deposit-taking- International Review of Financial Analysis - Volume 36, December 2014, Pages 71-77

Werner, Richard A. (Jan. 2015)- The Credit Creation Theory of Banking, the only theory consistent with empirical evidence 
Wicksell, Knut (1907). The influence of the rate of interest on prices. Economic Journal, 17, pp. 213-220. Wicksell, Knut., 1946 (1935) - Lectures on Political Economy. Vol. II: Money. London: G. Routledge\& Sons. Williams, John C. (July 2012) - Monetary Policy, Money, and Inflation Withers, Hartley (1918). The Business of Finance, London, John Murray, Albemarle Street, W. Wray, L. Randall (May 2012), 'Introduction to an Alternative History of Money', Working Paper No. 717 